\title{
Identification and Characterization of Microbial Community in the Coelomic Fluid of Earthworm (Aporrectodea molleri)
}

\author{
Lamia Yakkou ${ }^{1 *}$, Sofia Houida' ${ }^{1}$ Jorge Domínguez ${ }^{2}$, Mohammed Raouane ${ }^{1}$, Souad Amghar ${ }^{1}$, and Abdellatif El Harti ${ }^{1}$ \\ ${ }^{1}$ Reserch Team : Lumbricidae, Improving Soil Productivity and Environment (LAPSE), Centre "Eau, Ressources Naturelles, Environnement et \\ Développement Durable (CERNE2D) » Mohammed V University in Rabat, Ecole Normale Supérieure (ENS). Avenue Med Belhassan El \\ Ouazani. BP 5118, Takaddoum-Rabat, Morocco \\ ${ }^{2}$ Grupo de Ecoloxía Animal (GEA), Universidade de Vigo, E-36310 Vigo, Spain
}

Received: April 26, 2021 / Revised: May 12, 2021 / Accepted: May 18, 2021

\begin{abstract}
Earthworms play an important role in soil fertilization, interacting continually with microorganisms. This study aims to demonstrate the existence of beneficial microorganisms living in the earthworm's immune system, the coelomic fluid. To achieve this goal, a molecular identification technique was performed, using cytochrome c oxidase I (COI) barcoding to identify abundant endogenic earthworms inhabiting the temperate zone of Rabat, Morocco. Then, $16 \mathrm{~S}$ rDNA and ITS sequencing techniques were adopted for bacteria and fungi, respectively. Biochemical analysis, showed the ability of bacteria to produce characteristic enzymes and utilize substrates. Qualitative screening of plant growth-promoting traits, including nitrogen fixation, phosphate and potassium solubilization, and indole acetic acid (IAA) production, was also performed. The result of mitochondrial COI barcoding allowed the identification of the earthworm species Aporrectodea molleri. Phenotypic and genotypic studies of the sixteen isolated bacteria and the two isolated fungi showed that they belong to the Pseudomonas, Aeromonas, Bacillus, Buttiauxella, Enterobacter, Pantoea, and Raoultella, and the Penicillium genera, respectively. Most of the isolated bacteria in the coelomic fluid showed the ability to produce $\beta$-glucosidase, $\beta$-glucosaminidase, Glutamyl- $\beta$-naphthylamidase, and aminopeptidase enzymes, utilizing substrates like aliphatic thiol, sorbitol, and fatty acid ester. Furthermore, three bacteria were able to fix nitrogen, solubilize phosphate and potassium, and produce IAA. This initial study demonstrated that despite the immune property of earthworms' coelomic fluid, it harbors beneficial microorganisms. Thus, the presence of resistant microorganisms in the earthworm's immune system highlights a possible selection process at the coelomic fluid level.
\end{abstract}

Keywords: Aporrectodea molleri, plant growth-promoting rhizobacteria (PGPR), coelomic fluid, earthworm.

\section{Introduction}

Earthworms belong to the Annelidae, family of Lumbricidae, class of oligochaetes, which evolved at the end of the Precambrian and includes more than 8000

*Corresponding author

Tel.: +(212) 675504809

E-mail: lamia_yakkou@um5.ac.ma species [1]. They occupy a unique position in the animal kingdom and have successfully invaded terrestrial habitats [2]. Moreover, earthworms play an important role in temperate terrestrial ecosystems; they fertilize soils by modifying their physicochemical and biological properties (soil texture, regulation of biogeochemical cycles, etc.) [1, 3-5]. In order to carry out these actions, earthworms must interact with other components of the soil ecosystem, such as microflora (bacteria, fungi, etc.) 
[6]. In several studies, it has been shown that soil-level transformations involve synergistic interactions between earthworms and microorganisms. Furthermore, the presence of earthworms in soil has a great influence on soil microbial community structure and activity [7]. This can be strongly related to earthworm's dispersal activity within the created burrows [8]. Nevertheless, because of their limited ability to disperse within the soil, a large proportion of soil microorganisms are inactive, at any time, waiting for suitable conditions to promote higher levels of activity [9]. The abundant population of earthworms in soil provide an ideal environment for enhanced activity levels or multiplication of some selected microorganisms in the gut. Therefore, the most microorganisms stuied in earthworms were limited on microbial communities ingested with the soil and passed through the earthworm gut, considering the intestine is the only internal organ in constant contact with soil microorganisms $[6,10,11]$.

The coelom, which grows in several groups of invertebrates, including earthworms, in the form of a large cavity, would be an ideal area for colonization by pathogens and parasites. The clearance of bacteria after experimental injection of bacteria into the coelomic fluid (CF) is usually complete within $48 \mathrm{~h}$ [12]. Therefore, this liquid could be considered aseptic. However, the $\mathrm{CF}$ of earthworms is in continuous contact with the external environment through excretory organs, nephridia and pores that exist on the external surface of the earthworm [12]. Thus, despite the immune property of this fluid, we couldn't neglect the possibility of a probable selection of microorganisms at this level. Hence, the mean aim of this study is to perform a microbiological study by isolating culturable microorganisms, that could live in mutual association with the earthworm at the level of the immune system. The studied earthworm, which will be molecularly identified, is an endogenic type present abundantly in the temperate region of $\mathrm{Bou}$ Regreg-Akrach, Rabat-Morocco.

Knowing the continuous movement of earthworms, specially endogenies types, through the soil matrix, and considering the large population of beneficial plant growth rhizobacteria (PGPR) in the drilosphere and the rhizosphere, we are also interested in screening, qualitatively, bacteria with plant growth promoting potential.

\section{Materials and Methods}

\section{Earthworm sampling}

Earthworm sampling was carried out in Sidi Mohammed Ben Abdallah (SMBA) dam's surrounding soil, Bou Regreg-Akrach region, Rabat (Latitude: 33.95584800, Longitude: -6.72186300), Morocco. The dam of SMBA is located about $20 \mathrm{~km}$ south-east of Rabat-Salé, on Bou Regreg river.

Earthworms were collected in February 2019 during their peak period of activity in temperate climatic conditions (the average air temperature was close to $7^{\circ} \mathrm{C}$ ) in order to avoid the period of dormancy. Soil pits $(20 \times 20 \times$ $20 \mathrm{~cm}$ ) were dug using a spade and earthworms were hand-sorted in the field. The earthworms collected were intended for morphological identification, as well as for molecular analysis and other experimental work. Specimens were first categorized into morphospecies based on their morphology, size, color and behavior. Adult earthworms with clitellum were weighed fresh (without emptying the intestinal contents), counted, and separated based on the identification key [13]. The abundant earthworm was selected for molecular identification. From this earthworm, the isolation of culturable microorganisms at the level of $\mathrm{CF}$ was carried out.

\section{Molecular identification of earthworm}

Molecular identification of earthworm was performed in Spain, Grupo de Ecoloxía Animal (GEA), Universidade de Vigo, E-36310 Vigo. After washing earthworm with deionized water (D.I.W) and storing it in absolute ethanol, tissue samples were taken and the genomic DNA was extracted. Two universal invertebrate primers COI (LC01490 and HC02198; [14] : COI F LCO1490 GGTCAACAAATCATAAAGATATTGG and COI R HC012198 TAAACTTCAGGGTGACCAAAAAATCA, were used to amplify the DNA fragment encoding the cytochrome oxidase. The PCR reaction $(40 \mu \mathrm{l})$ consisted of Master Mix $(38 \mu \mathrm{l}): \mathrm{H} 2 \mathrm{O}$ PCR $=28.2 \mu \mathrm{l}$, Primer F $(10 \mu \mathrm{M})=2 \mu \mathrm{l}$, Primer R $(10 \mu \mathrm{M})=2 \mu \mathrm{l}$, Buffer Biotools (10x): $\mathrm{Mg}=4 \mu \mathrm{l}$, $\mathrm{dNTPs}=0.8 \mu \mathrm{l}$, Biotools Polymerase $(1 \mathrm{U} / \mathrm{ul})=1 \mu \mathrm{l}$, and $2 \mu \mathrm{l}$ of DNA template. The thermocycling protocol comprising an initial denaturation at $95^{\circ} \mathrm{C}(3 \mathrm{~min}), 40$ cycles of denaturation at $94^{\circ} \mathrm{C}(30 \mathrm{sec})$, hybridization at $45^{\circ} \mathrm{C}$ $(45 \mathrm{sec})$ and extension at $72^{\circ} \mathrm{C}(1 \mathrm{~min})$, followed by a final extension at $72^{\circ} \mathrm{C}$ (5 min). Negative controls were 
included to detect potential contamination. PCR products were sequenced in both directions using the Terminator Cycle Sequencing Kit following the protocol manufacturer's instructions.

\section{Isolation of microorganisms from the coelomic fluid}

The identified earthworm sample, from which the isolation was performed, were placed, aseptically, in a sterile bag and transferred to the laboratory within $4 \mathrm{~h}$. The earthworm was washed with sterile distilled water to remove soil and roots. They were then fasted for 10 days in sterile glass petri dishes to avoid contamination by castings during isolation. Prior to puncture, the surface of an individual adult earthworm was disinfected by deceiving the worm in 1\% Tween for $1 \mathrm{~min}$. Then, the earthworm was washed in series four times with sterile deionised water and dried on sterile filter paper. A swab sample from the surface of the earthworm was taken, in order to check if some microorganisms could still attach to the surface after disinfection operation. The earthworm specimen was then placed in a sterile plastic bag to immobilize it and control its movements. A puncture at the lateral level of the posterior part of the earthworm was performed using a sterile glass capillary. The coelomic fluid of the earthworm was collected and homogenized in tube containing $3 \mathrm{ml}$ of BHI (Brain Heart Infusion) liquid media. Each $0.1 \mathrm{ml}$ of the homogenate was deposited on four different solid media:

- Brain Heart Infusion (BHI), - Medium prepared from earthworm's crude extract (ECEx), - Urea, - PDA (Potatoes Dextrose Agar) supplemented with chloramphenicol.

The crude extract (ECEx) was obtained by maceration in oven $\left(60^{\circ} \mathrm{C}\right)$, executing successive baths of distilled water from a batch of dried died earthworms. The residue, obtained after drying is consisting entirely of watersoluble matter. This residue constituted the crude extract of earthworms from which the ECEx culture medium was prepared (dry matter concentration: $0.25 \mathrm{~g}$ per $100 \mathrm{ml})$.

The prepared culture media were incubated at 30 and $25^{\circ} \mathrm{C}$, respectively, for 7 days. Bacterial colonies and fungi were selected based on their morphological characteristics such as size, color and appearance. For the pure culture, the colonies were sub cultured and stored in a BHI liquid media supplemented with $20 \%$ glycerol, at $-20^{\circ} \mathrm{C}$ for later use.

\section{Phenotypic characterization of isolates}

The isolates were examined for colony and cell morphology, as well as for motility. Colony morphology was described using standard microbiological criteria, followed by Gram stain and microscopic observation of cells [15]. Biochemical tests were also performed using miniaturized and standardized galleries of biochemical tests: RapID remel (ThermoFisher Scientific).

\section{Bacteria Identification: DNA extraction, 16S rDNA amplifi- cation and sequencing}

The sequencing was carried out in the URATRS laboratory at CNRST Rabat, MOROCCO. Isolates with different phenotypic characteristics were selected. The bacterial DNA of each isolate was extracted from a pure bacterial culture according to the method provided by the BIOLINE "Isolate II Genomic DNA Kit" platform kit. The 16S rDNA of selected isolates was amplified, in order to obtain an amplicon of $1500 \mathrm{bp}$ using the universal primers $\mathrm{Fd} 1$ and RP2, according to the following protocol: the reaction mixture contained $(25 \mathrm{ul}): 10 \mu \mathrm{l}$ of sequencing buffer (2x Mix MyTaq from Bioline), $2 \mu \mathrm{l}$ of the FD110 $\mu \mathrm{M}$ primer, $2 \mu \mathrm{l}$ of the $10 \mu \mathrm{M}$ RP2 primer, $130 \mathrm{ng}$ of DNA template, and ultrapure water (for adjusting the volume to $25 \mu \mathrm{l}$ ). The PCR program used for amplification was as follows: $95^{\circ} \mathrm{C}, 1 \mathrm{~min}$; $\left(95^{\circ} \mathrm{C}\right.$, $\left.15 \mathrm{sec} ; 52^{\circ} \mathrm{C}, 20 \mathrm{sec} ; 72^{\circ} \mathrm{C}, 15 \mathrm{sec}\right) 35$ times; $72^{\circ} \mathrm{C}, 3 \mathrm{~min}$ (Device: ABI "Verity" thermal cycler). Sequencing reactions were performed in 96-well PCR plates using the sequencing kit (Big Dye Terminator version 3.1 or version 1.1 cycle sequencing-Applied Biosystems).

\section{Fungus identification: DNA extraction, ITS1 and ITS4 amplification and sequencing}

The isolates were placed on potato dextrose agar (PDA) medium containing chloramphenicol $(0.4 \mu \mathrm{g} / \mathrm{l}$ PDA). The plates were incubated at $25^{\circ} \mathrm{C}$ for 7 days to obtain a pure culture. A suspension containing the fungal spores was prepared in an ependorf. DNA from each isolate was extracted using the Genomic DNA Kit (Bioline). The DNA concentration obtained for each isolate was measured by Nanodrop. The amplification reaction was performed using the Kit MyTaq ExtractPCR 2X (Bioline), according to the manufacturer's 
instructions. The amplified ITS were purified and eluted in sterile distilled water. Finally, the sequencing was carried out in the URATRS (Scientific Research Technical Support Units) laboratory at CNRST (The National Center for Scientific and Technical Research) Rabat, MOROCCO.

\section{Phylogenetic analysis of DNA sequences}

The sequence information was imported into the DNA Dragon program for assembly ("DNA Dragon: Sequence Contig DNA assembly software"). The assembled sequence of COI, also 16S rDNA and ITS rDNA from each isolate, were compared to that of type strains conserved in the GenBank database. Sequence similarity searches were performed using the BLAST program on the NCBI site. The strains with a high percentage of similarity to the isolate were then imported into MEGA $\mathrm{X}$ software so that their sequences were aligned [16]. Nucleotide substitution rates were calculated after alignment and phylogenetic trees were constructed using the "Neighbor-joining" method [17].

The GenBank accession number of the sequence reported in this paper are: MT878074, MT576611, MT576622, MT576620, MT576621, MT576623, MT576614, MT576615, MT576612, MT576624, MW282170, MT576613, MT576619, MT576616, MT576618, MT576610, MT576617, MW244587, MW244588.

\section{Qualitative screening of bacteria with potential plant growth promoting traits}

The identified isolates were subjected to qualitative tests, in order to demonstrate their possible potential to promote plant growth. The ability of isolates to bind nitrogen was revealed on Nitrogen free media Ashby [18]. The phosphate solubilizing potential was demonstrated on solid Nautiyal medium (modified PVK) [19]. Then, the solubilizing isolates of an insoluble form of potassium were selected on Alexandrov medium prepared on the basis of Feldspar powder [20]. Finally, the IAA test was performed in liquid medium of yeast extract Mannitol supplemented with $3 \mathrm{~g} / \mathrm{l}$ of tryptophan according to the protocol of Shokri and Emtiazi [21]. On the basis of visual observation, the positive and negative test was recorded as + and -, respectively.

\section{Results}

\section{Molecular identification of earthworm}

The sampling of earthworms in the studied region (Bou Regreg- Akrach, Morocco) showed the presence of three morphologically different genera of earthworms. The abundant earthworm was selected for molecular identification. From this earthworm, the isolation of culturable microorganisms at the level of the coelomic fluid (CF) was carried out.

Mitochondrial COI barcoding technique allowed us to identify the abundant earthworm in Bou RegregAkkrach region. Morphologic and phylogenetic studies showed that the COI sequence was much nearest to the specie Aporrectodea molleri (Accession number: MT878074) (Fig. 1).

\section{Microbial community of the coelomic fluid}

The structure of the culturable bacterial community of the $\mathrm{CF}$ of the newly identified earthworm was analysed. In total, 70 colonies grew on the 4 different culture media used (BHI, ECEx, Urea and PDA). The BHI culture medium allowed the growth of more bacterial colonies (34\%), with different morphological appearance, followed by the ECEx medium (29\%), and the Urea

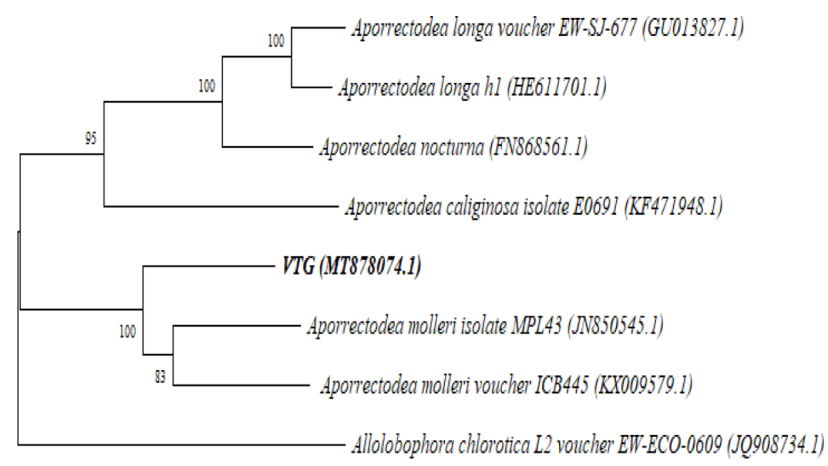

0.020

Fig. 1. Phylogenetic trees obtained for the abundant earthworm of the region Akkrach (Rabat-Morocco), by sequencing the COI locus. Numbers at the nodes indicate percentage bootstrap values (\%) support obtained in 1000 replications. The GenBank accession numbers for each sequence are shown adjacent to each strain. The scale represents 0.02 substitutions per site for COI segment. 
Table 1. Number of Aporrectodea molleri's coelomic fluid isolates according to the isolation culture medium.

\begin{tabular}{cc}
\hline Culture media & Number of isolates (\%) \\
\hline BHI & $24(34 \%)$ \\
ECEx & $20(29 \%)$ \\
Urea & $18(26 \%)$ \\
PDA & $8(11 \%)$ \\
\hline
\end{tabular}

medium (26\%) (Table 1). We noted that, most of the bacteria grown on the ECEx and BHI media also grew on the urea medium.

\section{Phenotypic characterization of isolates}

Based on the morphological appearance of colonies after subculturing and the results of fresh microscopic examination and Gram staining, catalase test and oxi- dase test, 28 different bacterial isolates could be distinguished. All the 28 bacterial isolates were selected for identification by $16 \mathrm{~S}$ rDNA molecular technique.

Two morphologically different fungi were selected for molecular identification based on sequencing ITS spacer region.

Microscopic examination as well as the biochemical tests were carried out on the molecular identified isolates a shown in the Tables 2 and 3 .

All isolates were motile, catalase positive, and only one was cocci and 2 isolates were strict aerobic.

Approximately 81\% (13/16) of the CF isolates were catalase positive, motile, aero-anaeobic bacilli that grew at temperatures between $28^{\circ} \mathrm{C}$ and $30^{\circ} \mathrm{C}$. Out of 16,10 isolates were Gram negative bacteria, which represent $63 \%$ (Table 2 and 3).

Most of gram-negative bacteria showed the ability to

Table 2. Phenotypic characteristics of the $10 \mathrm{Gram}-$ negative bacteria isolated from the coelomic fluid of the earthworm Aporrectodea molleri.

\begin{tabular}{|c|c|c|c|c|c|c|c|c|c|c|c|}
\hline & Isolate & LC13 & LC40 & LC2 & LC68 & LC67 & LC27 & LC4 & LC69 & LC72 & LC71 \\
\hline \multicolumn{2}{|c|}{ Optimal growth temperature } & $28^{\circ} \mathrm{C}$ & $28^{\circ} \mathrm{C}$ & $30^{\circ} \mathrm{C}$ & $30^{\circ} \mathrm{C}$ & $30^{\circ} \mathrm{C}$ & $28^{\circ} \mathrm{C}$ & $30^{\circ} \mathrm{C}$ & $30^{\circ} \mathrm{C}$ & $30^{\circ} \mathrm{C}$ & $30^{\circ} \mathrm{C}$ \\
\hline \multicolumn{2}{|c|}{ Respiratory mode ${ }^{a}$} & Facult & Facult & Facult & Facult & Facult & Facult & Facult & Aero & Aero & Facult \\
\hline \multicolumn{2}{|l|}{ Gram } & - & - & - & - & - & - & - & - & - & - \\
\hline \multicolumn{2}{|l|}{ Shape } & bacille & bacille & bacille & bacille & bacille & bacille & bacille & bacille & bacille & bacille \\
\hline \multicolumn{2}{|l|}{ Motility } & + & + & + & + & + & + & + & + & + & + \\
\hline \multirow[t]{13}{*}{ Produced enzyme } & Catalase & + & + & + & + & + & + & + & + & + & + \\
\hline & Oxydase & + & + & - & - & - & - & - & + & + & + \\
\hline & Arginine-dihydrolase & - & - & - & - & + & - & - & - & - & + \\
\hline & Ornithine-decarboxylase & - & - & - & + & + & - & - & - & - & - \\
\hline & Lysine-decarboxylase & - & - & + & + & - & - & + & - & - & - \\
\hline & $\beta$-glucuronidase & - & - & - & - & - & - & - & - & - & - \\
\hline & $\beta$-galactosidase & + & - & $+/-$ & - & $+/-$ & - & - & - & $+/-$ & - \\
\hline & $\beta$-glucosidase & + & + & + & + & - & + & + & - & - & - \\
\hline & $\beta$-xylosidase & - & - & + & + & + & - & + & - & - & - \\
\hline & $\beta$-glucosaminidase & + & + & + & + & + & - & - & - & + & - \\
\hline & Proline- $\beta$-naphthylamidase & + & + & - & - & - & - & - & $+/-$ & $+/-$ & - \\
\hline & Glutamyl- $\beta$-naphthylamidase & - & - & + & + & + & + & + & + & + & + \\
\hline & Pyrrolidonyl- $\beta$-naphthylamidase & - & - & - & - & + & + & + & - & - & - \\
\hline \multirow[t]{5}{*}{ Used substrate } & Malonate & - & - & - & - & + & + & + & + & - & - \\
\hline & Aliphatic thiol & - & + & - & + & - & + & - & + & + & - \\
\hline & Fatty acid ester & + & + & - & - & - & - & - & - & - & + \\
\hline & Sugar aldehyde & - & - & - & - & - & - & + & - & - & - \\
\hline & Sorbitol & - & - & + & + & + & - & + & - & + & - \\
\hline
\end{tabular}

${ }^{\mathrm{a}}$ Aero (Aerobic), Facult (Facultative), + (positive test) / - (negative test) 
Table 3. Phenotypic characteristics of the 6 Gram-positive bacteria isolated from the coelomic fluid of the earthworm Aporrectodea molleri.

\begin{tabular}{|c|c|c|c|c|c|c|c|}
\hline & Isolate & LC47 & LC12 & LC15 & LC9 & LC31 & LC46 \\
\hline \multicolumn{2}{|c|}{ Optimal growth temperature } & $30^{\circ} \mathrm{C}$ & $30^{\circ} \mathrm{C}$ & $30^{\circ} \mathrm{C}$ & $30^{\circ} \mathrm{C}$ & $30^{\circ} \mathrm{C}$ & $30^{\circ} \mathrm{C}$ \\
\hline \multicolumn{2}{|c|}{ Respiratory mode ${ }^{a}$} & Facult & Facult & Facult & Facult & Facult & Facult \\
\hline \multicolumn{2}{|l|}{ Gram } & + & + & + & + & + & + \\
\hline \multicolumn{2}{|l|}{ Shape } & bacille & bacille & bacille & bacille & bacille & Cocci \\
\hline \multicolumn{2}{|l|}{ Motility } & + & + & + & + & + & + \\
\hline \multirow[t]{15}{*}{ Produced enzyme } & Catalase & + & + & + & + & + & + \\
\hline & Oxydase & - & - & - & - & - & - \\
\hline & Arginine-dihydrolase & - & - & - & - & - & - \\
\hline & Ornithine-decarboxylase & - & - & - & - & - & - \\
\hline & Phosphatase & - & + & - & - & - & - \\
\hline & a-glucosidase & + & + & - & - & - & - \\
\hline & $\beta$-glucosidase & - & - & - & - & - & - \\
\hline & $\beta$-galactosidase & - & - & - & - & - & - \\
\hline & $\beta$-glucuronidase & - & - & - & - & - & - \\
\hline & $\beta$-glucosaminidase & - & - & - & - & - & - \\
\hline & Pyrrolidine aminopeptidase & - & - & - & - & - & - \\
\hline & Arginine aminopeptidase & + & + & + & + & + & + \\
\hline & Alanine aminopeptidase & + & + & + & + & + & + \\
\hline & Leucine aminopeptidase & + & + & - & - & - & - \\
\hline & Leucyl-glycine peptidase & - & - & - & - & - & - \\
\hline \multirow[t]{3}{*}{ Used substrate } & Fatty acid ester & + & + & + & - & - & + \\
\hline & Sucrose & + & + & - & - & - & + \\
\hline & Mannose & + & + & - & - & - & + \\
\hline
\end{tabular}

${ }^{\mathrm{a}}$ Aero (Aerobic), Facult (Facultative), + (positive test) / - (negative test)

produce $\beta$-glucosidase, $\beta$-glucosaminidase and glutamyl$\beta$-naphthylamidase enzymes, and they can utilize substrate like aliphatic thiol and sorbitol. The enzymes produced by most Gram-positive bacteria were arginine aminopeptidase and alanine aminopeptidase, and the substrate was the fatty acid ester (Table 2 and 3).

\section{Molecular identification of bacterial isolates}

To identify CF isolates (Bacteria and fungi) at the species level, molecular phylogenetic trees were constructed based on 16S rDNA and ITS sequences, using the Neighbor-Joining method for evolutionary distances. The results of the phylogenetic study of the CF bacteria and fungi were shown in Figs. 2 and Fig. 3, respectively. The results showed that the 28 bacterial isolates were phylogenetically close to 16 different bacterial species, which belong to 5 different bacterial families.
Among the isolated bacteria, 31\% (5/16) belong to the Bacilliaceae family, 31\% (5/16) to the Enterobacteriacae family, $19 \%$ (3/16) to Pseudomonacae, 13\% to Aeromonacae (2/16) and 6\% to Staphylococcaceae (1/16).

Among the isolated bacteria, 37\% belong to Gram positive bacteria distributed as follows: $31 \%(5 / 16)$ belong to the Bacilliaceae family and $6 \%(1 / 16)$ to Staphylococcaceae. The rest of the isolates 63\% (10/16) were Gram negative represented by 3 families: Enterobacteriacae, 31\% (5/16), Pseudomonacae, 19\% (3/ 16) and Aeromonacae 13\% (2/16).

Generally, the similarities sequences of the isolates were greater than $97.58 \%$ (cut off) to their relative reference strains in the GenBank database (Table 4).

Five bacterial isolates belonging to Enterobacteriaceae family were phylogenetically closers to Raoultella planticola ATCC 33531 (LC4 (1522 nt)), Klebsiella aerogenes 


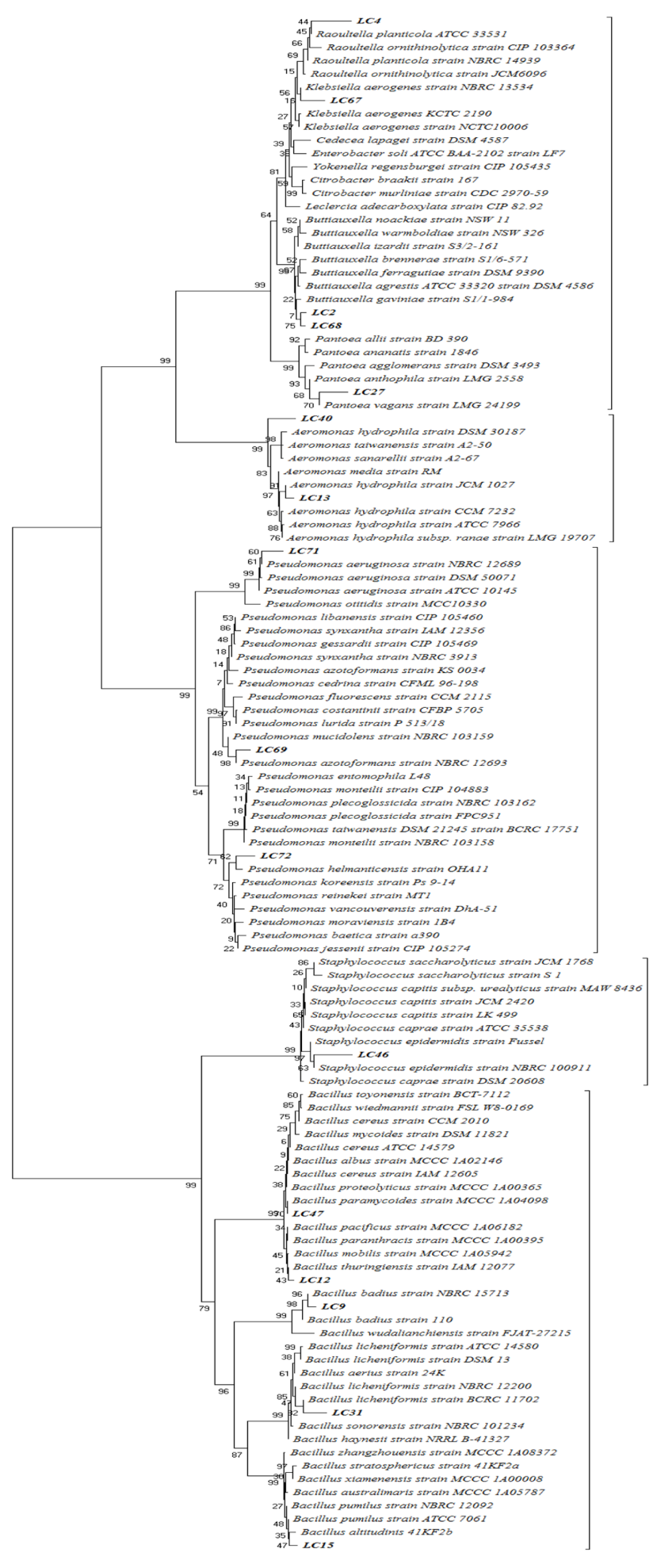

Fig. 2. Phylogenetic tree showing the position of the strains isolated from the coelomic fluid of earthworm Aporrectodea molleri. The evolutionary distances were computed using bootstrap test (1500 replicates) Kimura 2-parameter.
NBRC 13534 (LC67 (1518 nt)), Buttiauxella gaviniae S1 /1-984 (LC2 and LC68 (1508 and 1509 nt)) and Pantoea vagans LMG 24199 (LC27 (1514 nt)), with a similarity percentage of $98.52 \%, 98.91 \%, 98.39,99.26 \%$ and 98.87 , respectively (Fig. 2, Table 4). Despite that the isolates LC2 and LC68 are close to the same cluster, they are phylogenetically different strains.

The bacterial isolates LC40 and LC13 belong to Aeromonas genus (Fig. 2). The genetic sequence of $16 \mathrm{~S}$ rDNA from strain LC40 (1530 nt) did not represent a close phylogenetic similarity with the 16S rDNA gene sequences recorded in the Genbank Database. The 16S rDNA gene sequence of LC13 (1529 nt) was phylogenetically closest to the $16 \mathrm{~S}$ rDNA gene sequences of Aeromonas hydrophila JCM 1027 with a sequence similarity of $99.73 \%$.

The genus of Pseudomonas was divided into 3 phylogenetically different species (Fig. 2). LC71 (1505 nt), LC69 (1535 nt), and LC72 (1517 nt) had the closest similarities at a percentage of $99.11 \%, 99.45 \%$ and $98.71 \%$, with Pseudomonas aeroginosa strain NBRC 12689, Pseudomonas azotoformans NBRC 12693 and Pseudomonas helmanticensis strain OHA11, respectively (Fig. 2, Table 4).

From the $\mathrm{CF}$, it was possible to isolate a strain belonging to the Staphylococcaceae family. Isolate LC46 was phylogenetically close to the $16 \mathrm{~S}$ rDNA gene sequences of Staphylococcus epidermidis NBRC 100911, with a sequence similarity of $97.58 \%$ (Fig. 2, Table 4).

Bacillus genus included five bacterial species. LC47 (1517 nt), LC12 (1201 nt), LC9 (1529 nt), LC31 (1536 nt) and LC15 (1205 nt) were closer to Bacillus paramycoides MCCC 1A04098, Bacillus thuringiensis IAM 12077, Bacillus badius NBRC 15713, Bacillus licheniformis BCRC 11702, and Bacillus altitudinis 41KF2b with rates of $16 \mathrm{~S}$ rDNA sequence similarity of $99.93 \%, 99.6 \%$, 99.6\%, $98.25 \%$ and $100 \%$, respectively (Fig. 2 and Table 4).

\section{Molecular identification of fungi isolates}

Based on ITS1 and ITS4 sequences, the fungi LC44 and LC51 showed a phylogenetic similarity to the species Penicillium griseofulvum CBS 185.27 and Penicillium polonicum CBS 222.28 , with $100 \%$ and $98.87 \%$ percentage of identity, respectively (Fig. 3 and Table 4). 
Table 4. Sequence similarities of $\mathbf{1 6}$ bacteria and $\mathbf{2}$ fungi isolated from the coelomic fluid of the earthworm Aporrectodea molleri, to closest relatives.

\begin{tabular}{|c|c|c|c|c|c|}
\hline Strains & Nearest Species & $\begin{array}{c}\text { Query } \\
\text { length (nt) }\end{array}$ & $\begin{array}{c}\text { Identity } \\
(\%)\end{array}$ & $\begin{array}{c}\text { Accession } \\
\text { Number }\end{array}$ & $\begin{array}{c}\text { Number of } \\
\text { nucleotides (nt) }\end{array}$ \\
\hline LC4 & Raoultella planticola ATCC $33531^{\top}$ & $93 \%$ & $98.52 \%$ & MT576611 & 1522 \\
\hline LC67 & Klebsiella aerogenes NBRC $13534^{\top}$ & $96 \%$ & $98.91 \%$ & MT576622 & 1518 \\
\hline LC2 & Buttiauxella gaviniae $\mathrm{S} 1 / 1-984^{\top}$ & $98 \%$ & $98.39 \%$ & MT576620 & 1508 \\
\hline LC68 & Buttiauxella gaviniae $\mathrm{S} 1 / 1-984^{\top}$ & $98 \%$ & $99.26 \%$ & MT576621 & 1509 \\
\hline LC27 & Pantoea vagans LMG $24199^{\top}$ & $93 \%$ & $98.87 \%$ & MT576623 & 1514 \\
\hline LC40 & Aeromonas spp & - & - & MT576614 & 1530 \\
\hline $\mathrm{LC} 13$ & Aeromonas hydrophila JCM1027 & $96 \%$ & $99.73 \%$ & MT576615 & 1529 \\
\hline LC 71 & Pseudomonas aeruginosa NBRC $12689^{\top}$ & $97 \%$ & $99.11 \%$ & MT576612 & 1505 \\
\hline LC69 & Pseudomonas azotoformans NBRC $12693^{\top}$ & $96 \%$ & $99.45 \%$ & MT576624 & 1535 \\
\hline $\mathrm{LC} 72$ & Pseudomonas helmanticensis $\mathrm{OHA} 11^{\top}$ & $97 \%$ & $98.71 \%$ & MW282170 & 1517 \\
\hline LC46 & Staphylococus epidermidis NBRC $100911^{\top}$ & $96 \%$ & $97.58 \%$ & MT576613 & 1534 \\
\hline LC47 & Bacillus paramycoides MCCC $1 \mathrm{~A}^{04098^{\top}}$ & $99 \%$ & $99.93 \%$ & MT576619 & 1517 \\
\hline $\mathrm{LC} 12$ & Bacillus thuringiensis IAM $12077^{\top}$ & $97 \%$ & $99.6 \%$ & MT576616 & 1201 \\
\hline LC9 & Bacillus badius NBRC $15713^{\top}$ & $96 \%$ & $99.6 \%$ & MT576618 & 1529 \\
\hline LC31 & Bacillus licheniformis BCRC $11702^{\top}$ & $96 \%$ & $98.25 \%$ & MT576610 & 1536 \\
\hline LC15 & Bacillus altitudinis $41 \mathrm{KF} 2 \mathrm{~b}^{\top}$ & $96 \%$ & $100 \%$ & MT576617 & 1205 \\
\hline LC 44 & Penicillium griseofulvum CBS $185.27^{\top}$ & $100 \%$ & $100 \%$ & MW244587 & 188 \\
\hline LC51 & Penicillium polonicum CBS $222.28^{\top}$ & $93 \%$ & $98.87 \%$ & MW244588 & 188 \\
\hline
\end{tabular}

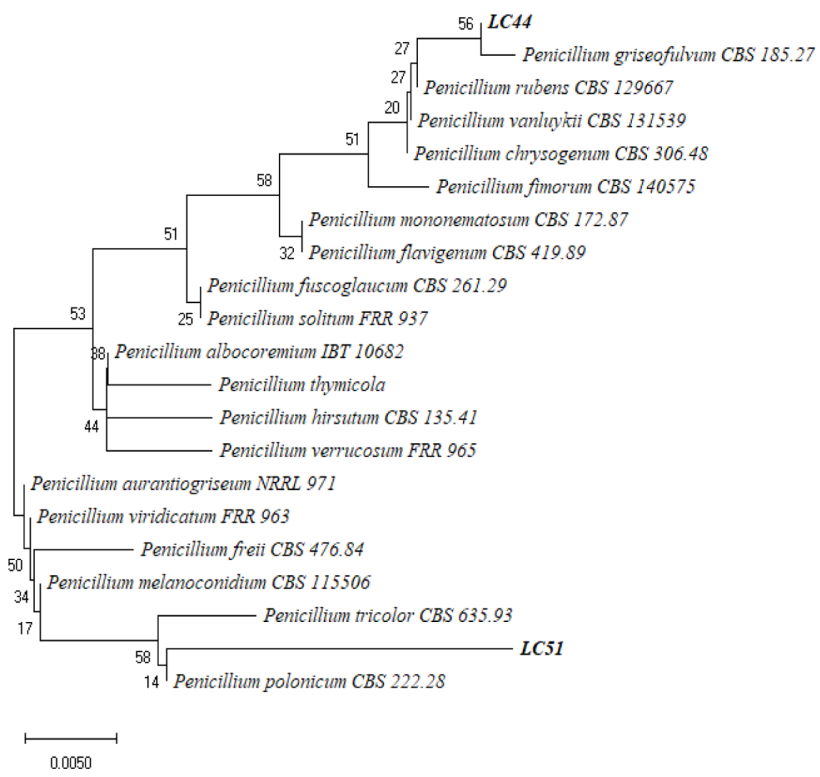

Fig. 3. Phylogenetic tree showing the position of the fungus isolated from the coelomic fluid of earthworm Aporrectodea molleri. The evolutionary distances were computed using bootstrap test (1500 replicates) Kimura 2-parameter.

\section{Earthworm's cutaneous surface isolates}

The bacteria isolated from the surface of earthworm

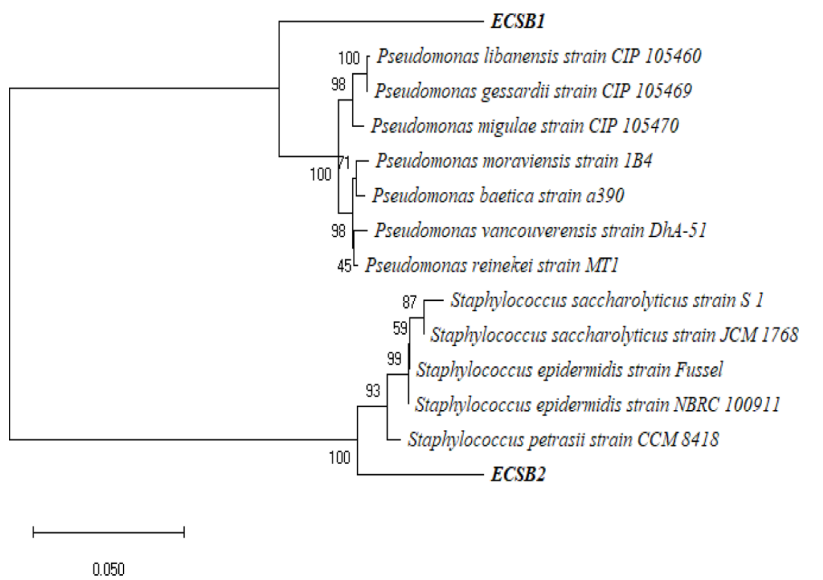

Fig. 4. Phylogenetic tree showing the position of the strains isolated from the surface of earthworm after disinfection: ECSB1 and ECSB2. The evolutionary distances were computed using bootstrap test (1500 replicates) Kimura 2-parameter.

and those resistant to the disinfection treatment, were also intended for molecular identification by amplification and sequencing of the $16 \mathrm{~S}$ rDNA gene. The phylogenetic analysis showed that earthworm's cutaneous surface bacteria (ECSB) were different from those of the CF. Cutaneous Surface bacteria ECSB1 and ECSB2 
were phylogenetically nearest to Pseudomonas reinekei MT1 and Staphylococcus petrasii CCM 8418, respectively (Fig. 4).

\section{Qualitative screening for PGP ability of isolated bacteria}

Table 5 represents the results of tests carried out in solid medium for the qualitative revelation of bacteria that have the ability of fixing nitrogen, solubilizing phosphate and potassium and those capable of producing the phytohormone IAA. Out of 16 tested bacteria, nine can fix atmospheric nitrogen while growing in Ashby media. The qualitative test on the solid PVK media showed that, four isolates formed a halo around the colonies, which means they can solubilize the insoluble form of phosphate Tricalcium phosphate. Six bacteria had the potential to solubilize insoluble form of potassium (Feldspar) in Alexandrov solid media. The qualitative test in liquid media supplied by Tryptophane, showed that among the 16 bacterial isolates of the $\mathrm{CF}$, eleven isolates can produce indole acetic acid (69\%). The isolated bacteria LC68, LC27 and LC71 showed a positive performance for the all 4 tests. These bacteria belong to Buttiauxella, Pantoea and Pseudomonas genera, respec- tively.

We notice that 10/16 isolates are positive for at least 2 tests and only 3/16 isolates (LC67, LC2 and LC72) are negative for the 4 tests.

Also, although the 2 isolates, LC2 and LC68 were phylogenetically close to the same species, they do not have the same potential. LC2 did not show any potential concerning the plant growth promoting traits.

\section{Discussion}

Our study aimed to demonstrate the existence of a symbiotic association between an abundant endogenic earthworm, inhabiting the temperate zone of Sidi Mohamed Ben Abdellah dam SMBA (Bou RegregAkrech, Morocco) and microorganisms living in the earthworm's immune system; the coelomic fluid (CF).

The abundant earthworm of the SMBA region belongs to the genera Aporrectodea. Unlike Aporrectodea caliginosa species, which has known effects in soil as priming the release of mobile and available micronutrients, Aporrectodea molleri specie is still not well studied concerning its role in the soil [23].

Table 5. Qualitative screenings of bacteria with the potential to fixe nitrogen, solubilize tricalcium phosphate and potassium, and produce IAA.

\begin{tabular}{|c|c|c|c|c|c|}
\hline Family & Strains & Nitrogen fixation & $\begin{array}{l}\text { Phosphate } \\
\text { solubilization }\end{array}$ & $\begin{array}{l}\text { Potassium } \\
\text { solubilization }\end{array}$ & IAA production \\
\hline \multirow[t]{5}{*}{ Enterobacteriaceae } & LC4 & + & - & + & - \\
\hline & LC67 & - & - & - & - \\
\hline & LC2 & - & - & - & - \\
\hline & LC68 & + & + & + & + \\
\hline & LC27 & + & + & + & + \\
\hline \multirow[t]{2}{*}{ Aeromonadacae } & LC40 & + & - & + & + \\
\hline & LC13 & - & - & + & + \\
\hline \multirow[t]{3}{*}{ Pseudomonadace } & LC 71 & + & + & + & + \\
\hline & LC69 & + & - & - & + \\
\hline & LC72 & - & - & - & - \\
\hline Staphylococcace & LC46 & + & + & - & - \\
\hline \multirow[t]{5}{*}{ Bacillaceae } & LC47 & + & - & - & + \\
\hline & LC12 & + & - & - & + \\
\hline & LC9 & - & - & - & + \\
\hline & LC31 & - & - & - & + \\
\hline & LC15 & - & - & - & + \\
\hline
\end{tabular}

+ (positive test) / - (negative test) 
The medium prepared from the freshly harvested earthworm extract (ECEx) allowed the growth of colonies of different sizes and appearances, as BHI medium. This result confirms that the medium prepared from whole earthworms is as rich as the BHI medium and allows the growth and isolation of bacteria that belong to different genera. This can be explained by studies which have shown that earthworms are very rich in protein (from $32.6 \%$ to $67.2 \%$ ), amino acids, fats (7 to $10 \%$ ), carbohydrates ( 8 to $20 \%$ ), minerals and various vitamins (2 to 3\%) [24-26]. Therefore, earthworm would constitute a favorable environment for the growth of exogenous bacteria and saprophytes fungi if it were not protected by an effective immune system.

The effectiveness of antimicrobial activity of earthworm's CF has been tested in a fair number of scientific researches [27-29]. Innate immunity is maintained by cellular components and numerous active immunological (antimicrobial) molecules [30]. Antimicrobial peptides represent a firstline innate immune response. One of the widely distributed antimicrobial peptides is lysozyme. This protein cleaves the $\beta$-1,4-glycosidic bond between $\mathrm{N}$-acetylmuramic acid and $\mathrm{N}$-acetylglucosamine of peptiglycan of bacterial cell walls and thus effectively contributes to the protection against infections caused mainly by Gram-positive bacteria [31]. However, it has been found that the CF of earthworms contains molecules exert antimicrobial activity against both Gram-positive and Gram-negative bacteria, but, in particular against strains pathogenic for earthworms $[32,33]$. In the present study, Gram positive bacteria represented only $38 \%$ of total isolated bacteria. This let us suggest that the selection can be based either on membrane constitutions or a species-specific interaction. The very low number of fungi isolated from the $\mathrm{CF}$ can be explained by the fact that generally earthworms have a negative effect on fungus except some species. It has been suggested that some fungal species appear to be preferred while others are rejected, but the extent to which other earthworm species (particularly endogenic) select different fungal species is not well established. Moreover, we have to note that earthworms increase bacterial/ fungal ratio in the soil [8]. The fact that some fungi are selectively rejected by earthworms, can be related to their ability to affect the survival and growth of earthworms by producing toxins [28].
The presence of two bacteria belonging to staphylococcus genera in the surface of earthworm, reflect their resistance to disinfection treatment, or the protection by surface mucilage. Nevertheless, the cutaneous mucus of earthworm consists of several antimicrobial agents that provide a first line of defence against invading pathogens, but in the same time it is selective. Indeed, bacteriostasis of earthworm secretions increased significantly after exposure to $E$. coli and $S$. aureus, although no bacteriostatic effect was observed for $P$. aeruginosa [34].

The molecular analysis of CF's isolated bacteria, revealed the existence of 16 bacterial species belonging to 5 different families, namely: Aeromonaceae, Bacilliacae, Pseudomonaceae, Enterobacteriacae and Staphylococcaceae.

The present microbiological study firmed that CF, which fills the coelomic cavity, is not aseptic. In fact, each segment of the earthworm cavity interfaces with the external environment via excretory organs and dorsal pores which allow microorganisms to enter CF [12]. Therefore, CF interacts with soil microorganisms. The microorganisms which cross the epithelial barrier in $\mathrm{CF}$ are eliminated by the efficient innate defence mechanisms, just mentioned, which are provided by the coelomocytes and by various humoral antimicrobial factors involved in the direct elimination of invading bacteria. Yet, there may be a mutual symbiotic association which has caused some bacteria to survive under these conditions and which are not affected by the antimicrobial substances in this system. For the species of the earthworm A. molleri, from which the isolation was made, it is assumed that the 16 isolated bacterial species were selected by the earthworm and they live in symbiotic association at the level of its CF. Since earthworms live in the rhizosphere and feed on plant roots as organic matter, they promote the spread and growth of beneficial soil bacteria.

We mention that, among the isolated and identified species of $\mathrm{CF}$, there are species which their important role in the rhizosphere has been proved and which are qualified as beneficial bacteria for plant growth. Bacillus thuringiensis, Bacillus altitudinis, Bacillus licheniformis, Pseudomonas aeruginosa, Pseudomonas azotoformans, Pseudomonas helmanticensis, have effects on stimulating plant growth, and used in biocontrol and soil fertilization [35-39]. 
If we analyse the results of bacteria isolated from the intestine of earthworms, it can be noted that Aeromonas, Bacillus and Pseudomonas are the most dominant genera in different species of earthworms. Picón et al. [6] revealed the presence of a variety of bacterial strains in the intestine of earthworms (Eisenia andrei), among which 8 species, belonging to Pseudomonadaceae, Bacilliaceae and Enterobacteriaceae families, have been identified. In addition, Kim et al. [10] have proved the presence of Aeromonas Enterobacter and Bacillus genera, with Bacillus the most abundant genus, in the earthworm's gut.

Recent studies have proved the effect of bacteria associated to earthworm on the remediation and plant growth. Biswas et al. [40] have isolated three phosphate solubilizing bacteria (Bacillus megaterium, Staphylococcus haemolyticus and Bacillus licheniformis) from the gut of the earthworm Metaphire posthuma. In the study, it has been suggested that the three isolated phosphate solubilizing bacteria strains from earthworm gut possess intrinsic abilities of growth promotion, metal resistance, which could be exploited for plant growth promotion and bioremediation even under metal-stress conditions.

Based on our study it can be assumed that that earthworm, during their peristaltic movements, they are involved in the dynamics and the dispersion in the soil of beneficial bacteria, through the release of CF. This interaction is essential in the natural improvement of soil fertility.

To well understand the role of $\mathrm{CF}$ microorganisms, ulterior studies should be conducted and the role of CFassociated microorganisms should be tested in vivo for plant growth.

\section{Acknowledgments}

The work is carried out with the support of the National Center for Scientific and Technical Research (CNRST) within the framework of the Research Excellence Scholarships Program.

\section{Conflict of Interest}

The authors have no financial conflicts of interest to declare.

\section{References}

1. Feller C, Brown GG, Blanchart E, Deleporte P, Chernyanskii SS.
2003. Charles Darwin, earthworms and the natural sciences: Various lessons from past to future. Agric. Ecosyst. Environ. 99: 29-49.

2. Blouin M, Hodson ME, Delgado EA, Baker G, Brussaard L, Butt KR, et al. 2013. A review of earthworm impact on soil function and ecosystem services. Eur. J. Soil Sci. 64: 161-182.

3. Brown GG, Barois I, Lavelle P. 2000. Regulation of soil organic matter dynamics and microbial activity in the drilosphere and the role of interactions with other edaphic functional domains. Eur. J. Soil Biol. 36: 177-198.

4. Raouane M, El Harti A. 2016. Pouvoir neutralisant des $\mathrm{pH}$ acides par les excrétions cutanées de Lumbricus terrestris L. Bull. la Soc. Rdes Sci. Liege 85: 1-16.

5. El Harti A, Saghi M, Molina J, Teller G. 2001. Production de composés indoliques rhizogènes par le ver de terre Lumbricus terrestris. Can. J. Zool. 79: 1921-1932.

6. Picón MC, Teisaire ES, Zutara MS, Giunta SA. 2015. Identification of the intestinal microbial community of eisenia andrei (annelida: lumbricidae) raised in different substrates. Mun. Ent. Zool. 10: 101-106.

7. Aira M, Pérez-Losada M, Domínguez J. 2018. Diversity, structure and sources of bacterial communities in earthworm cocoons. Sci. Rep. 8: 6632.

8. Edwards CA. 2004. Earthworms Ecology. CRC press.

9. Lavelle $P$, Bignell $D$, Lepage $M$, Wolters $V$, Roger $P$, Ineson $P$, et al. 1997. Soil function in a changing world: The role of invertebrate ecosystem engineers. Eur. J. Soil Biol. 33: 159-193.

10. Kim HJ, Shin KH, Cha CJ, Hur HG. 2004. Analysis of aerobic and culturable bacterial community structures in earthworm (Eisenia fetida) intestine. Agric. Chem. Biotechnol. 47: 137-142.

11. Kim ES, Hong SW, Chung KS. 2011. Comparative analysis of bacterial diversity in the intestinal tract of earthworm (Eisenia fetida) using DGGE and pyrosequencing. Microbiol. Biotechnol. Lett. 39: 374-381.

12. Bilej M, Procházková $P$, Roubalová R, Škanta F, Dvořák J. 2018. Annelida: recognition of nonself in earthworms. pp. 161-172. In: Advances in comparative immunology. Springer International Publishing.

13. Sims WR, Gerard BM. 1985. Keys and notes for the identification and study of the species, brill arch. Linnean society of London, Estuarine and Brackish-Water Sciences Association.

14. Folmer O, Black M, Hoeh W, Lutz R, Vrijenhoek R. 1994. DNA primers for amplification of mitochondrial cytochrome c oxidase subunit I from diverse metazoan invertebrates. Mol. Mar. Biol. Biotechnol. 5: 294-299.

15. Garrity GM, Brenner DJ, Krieg NR, Staley JT. 2005. Bergey's manual of systematic bacteriology, Secon ed. Vol. two: The Proteobacteria, Part B: Gammaproteobacteria. Springer-Verlag New York Inc. 2: 883-904.

16. Kumar S, Stecher G, Li M, Knyaz C, Tamura K. 2018. MEGA X: Molecular evolutionary genetics analysis across computing platforms. Mol. Biol. Evol. 35: 1547-1549.

17. Saitou N, Nei M. 1987. The neighbor-joining method: A new method for reconstructing phylogenetic trees. Mol. Biol. Evol. 4: 
406-425.

18. Kirk PL. 1950. Kjeldahl method for total nitrogen. Anal. Chem. 22: 354-358.

19. Mehta S, Nautiyal CS. 2001. An efficient method for qualitative screening of phosphate-solubilizing bacteria. Curr. Microbiol. 43: 51-56.

20. Sugumaran P, Janarthanam B. 2007. Solubilization of potassiumcontaining minerals by bacteria and their effect on plant growth. World J. Agric. Sci. 3: 350-355.

21. Shokri D, Emtiazi G. 2010. Indole-3-acetic acid (IAA) production in symbiotic and non-symbiotic nitrogen-fixing bacteria and its optimization by taguchi design. Curr. Microbiol. 61: 217-225.

22. Benabdellouahad S. 2006. Structure, dynamique et typologies physico-chimiques et phytoplanctoniques de l'estuaire du bouregreg (côte atlantique marocaine). Dissertation, University Mohammed V Agdal.

23. Bityutskii NP, Maiorov El, Orlova NE. 2012. European Journal of Soil Biology The priming effects induced by earthworm mucus on mineralization and humification of plant residues. Eur. J. Soil Biol. 50: 1-6.

24. Damayanti E, Julendra H, Sofyan A. 2008. Antibacteria activity of earthworm meal (Lumbricus rubellus) with different methods to the Escherichia coli. pp. 54-60. In: National Food Seminar, Yogyakarta.

25. Istiqomah L, Sofyan A, Damayanti E, Julendra H. 2009. Amino acid profile of earthworm and earthworm meal (Lumbricus rubellus) for animal feedstuff. J. Indones Trop Anim. Agric. 34: 253-257.

26. Ghatnekar SD, Kavian M, Ghatnekar GS. 1995. Biomanagement of wastes through vermiculture. Ecology 10: 1-7.

27. Kathireswari P, Alakesan A, Abirami P, Sangeetha P. 2014. Antimicrobial activity of earthworm coelomic fluid against disease causing microorganisms. Int. J. Curr. Microbiol. Appl. Sci. 3: 608613.

28. Brown GG. 1995. How do earthworms affect microfloral and faunal community diversity? Plant Soil 170: 209-231.

29. Roubalová R, Prochazkova P, Dvorák J. 2015. The role of earthworm defense mechanisms in ecotoxicity studies. Invertebr. Surviv. J. 12: 203-213.

30. Stein E, Avtalion RR, Cooper EL. 1977. The coelomocytes of the earthworm Lumbricus terrestris: morphology and phagocytic properties. J. Morphol. 153: 467-477.

31. Bilej $M$, Procházková $P$, Šilerová $M$, Josková R. 2010. Earthworm immunity. Prog. Mol. Subcell. Biol. 15: 10-45.

32. Roch P, Lassegues M, Valembois P. 1991. Antibacterial activity of Eisenia fetida andrei coelomic fluid: III-Relationship within the polymorphic hemolysins. Dev. Comp. Immunol. 15: 27-32.

33. Valembois $P$, Lassègues $M$, Roch $P$, Vaillier J. 1985. Scanning electron-microscopic study of the involvement of coelomic cells in earthworm antibacterial defense. Cell Tissue Res. 240: 479-484.

34. Wang C, Sun Z, Zheng D, Liu X. 2011. Function of mucilaginous secretions in the antibacterial immunity system of Eisenia fetida. Pedobiologia (Jena) 54: S57-S62.

35. Brown GG, Feller C, Blanchart E, Deleporte P, Chernyanskii SS. 2003. With Darwin, earthworms turn intelligent and become human friends. Pedobiologia (Jena) 47: 924-933.

36. Sunar K, Dey P, Chakraborty U, Chakraborty B. 2015. Biocontrol ef fi cacy and plant growth promoting activity of Bacillus altitudinis isolated from Darjeeling hills, India. J. Basic Microbiol. 55: 91-104.

37. Bhattacharyya PN, Jha DK. 2012. Plant growth-promoting rhizobacteria (PGPR): Emergence in agriculture. World J. Microbiol. Biotechnol. 28: 1327-1350.

38. Yousra B. 2018. Diversity in the susceptibility of Botrytis cinerea strains to the biological control agent Pseudomonas helmanticensis. IOBC/WPRS Bull. 133: 100-104.

39. Mishra PK, Bisht SC, Jeevanandan K, Kumar S, Bisht JK, Bhatt JC. 2014. Synergistic effect of inoculating plant growth- promoting Pseudomonas spp. and Rhizobium leguminosarum-FB1 on growth and nutrient uptake of rajmash (Phaseolus vulgaris L.). Arch Agron. Soil Sci. 60: 799-815.

40. Sun Z, Liu K, Zhang J, Zhang Y. 2017. IAA producing Bacillus altitudinis alleviates iron stress in Triticum aestivum L. seedling by both bioleaching of iron and up-regulation of genes encoding ferritins. Plant Soil 419: 1-11.

41. Biswas JK, Banerjee A, Rai M, Naidu R, Biswas B, Vithanage M, et al. 2018. Potential application of selected metal resistant phosphate solubilizing bacteria isolated from the gut of earthworm (Metaphire posthuma) in plant growth promotion. Geoderma 330: 117-124. 